\title{
Hjernealdermennesket - Nikolas Rose og Joelle M. Abi-Rached om de nye neurovidenskaber
}

Nikolas Rose \& Joelle M. Abi-Rached:

Neuro: The New Brain Sciences and the Management of the Mind

Princeton University Press, 2013

344 sider, 24,95 USD.

Den britiske sociolog Nikolas Rose har siden 1990erne været en fremtrædende repræsentant for sociologisk og kulturanalytisk samtidsdiagnostik. Rose har især trådt filosofferne i beddingen ved at forankre spørgsmålet om 'hvad mennesket er' i neo-foucaultianske analyser af bl.a. psykologiens samt ledelses- og bioteknologiernes betydning for vores nutidige forståelse og forvaltning af selvet. $\mathrm{Og}$ af de værdier om autonomi, identitet, individualitet, frihed og valg, som vi knytter til dette selv.

Denne neo-foucaultianske grundskabelon genfindes som pejling af værket Neuro: The New Brain Sciences and the Management of the Mind fra 2013, som Rose har bedrevet i et samarbejde med den amerikanske videnskabshistoriker Joelle Abi-Rached. Som det også gør sig gældende i Roses øvrige værker, er Foucault først og fremmest med i hånden og ikke så meget $\mathrm{i}$ ånden i Neuro, som fokuserer på neurovidenskabernes implikationer for vores forståelse af, hvem vi er, og hvordan vi organiserer vores adfærd. Og hvordan skal det med Foucault forstås? Jo, kort før sin død proklamerer Foucault, at det generelle hovedsigte $\mathrm{i}$ hans modernitetsanalyser er et forsøg på at lave en rationalitetskritisk underminering af nogle tilsyneladende sandheder om, hvem vi er og bør være som mennesker, som har sedimenteret sig $\mathrm{i}$ vores samtid som historiske selvfølgeligheder. Denne underminering lader Foucault foregå gennem en pessimistisk påpegning af, hvordan enhver udvikling af tankesystemerne og de tilknyttede praksisser og institutioner - $\mathrm{i}$ vores sikkerhedsfikserede samtid rent faktisk rummer en mangfoldighed af farer. Altså, når samtidens mulighedsbetingelser og begrænsninger bliver 
analyseret ud fra en grundlæggende - og ofte uudtalt - insisteren på menneskets fundamentale frihed. Men, hos Rose og Abi-Racheed finder vi derimod spor af en angelsaksisk pragmatisme og nyttefokusering, der viser sig ved, at de i realiteten vender Foucaults bestræbelse på hovedet og drejer rationalitetskritikken af den moderne fornuft endnu 180 grader med næsen hjem mod start. Rose og Abi-Racheed ønsker ganske vist at give Neuro et moderat kritisk anstrøg. Men kritikken er først og fremmest spundet over et optimistisk hovedsigte, som kommer til udtryk i deres formulering af en generel sikkerhedsorienteret ambition med Neuro. Deres mål er nemlig at ville bruge værket til at dechifrere og afmystificere neurovidenskabernes implikationer for lige netop at kunne betrygge alle de skælvende modstandere inden for human- og samfundsvidenskaberne. Om hvad? Om at neurovidenskaberne slet ikke er så farlige, når vi blot er varlige.

Når denne analytiske tilgang så overhovedet er relevant, er det fordi Rose og Abi-Racheed har brugt deres samtidsdiagnostiske blik til at registrere, hvordan neurovidenskaberne i stigende grad er blevet et prisme for forståelsen af og omgangen med menneskets natur i vores kultur. Mange fremhæver gerne neurovidenskaberne som nøglen til et svar på livets dybeste spørgsmål om, hvad der overhovedet betinger, at vi er dem, vi er. Desuden definerer og forvalter samfundslivet i stigende grad individer ud fra en forestilling om hjernens betydning, og denne tendens er både begyndt at gennemsyre politik og lovgivning samt at indsnige sig i human- og samfundsvidenskaberne. Eftersom dette umiddelbart kan ligne gentagelsen af den historiske udvikling i begyndelsen af det 20 . århundrede, vil Rose og Abi-Racheed dobbeltsikre vores skridt og mane genfærd væk.

Neuro er først og fremmest et stykke samtidshistorie, og kernen i den historie kan bedst beskrives som et forsøg på at opdatere Foucaults idéhistoriske analyse af det kliniske blik i Klinikekens fodsel fra 1963. Det værk omfattede historien om, hvordan en ny måde at se på åbner den døde krop som vidensreservoir for den kliniske lægevidenskab omkring år 1800. Rose og Abi-Rached befatter sig med en mere nutidig, men bestemt ikke mindre informationspakket analyse af det neuromolekylære blik, der åbner hjernen som et helt igennem forståeligt og håndgribeligt organ for neurovidenska- 
berne. De seneste årtier har den teknologiske udvikling nemlig gjort en hel ny verden inde i hovedet på os selv synlig for videnskabelig udforskning og dermed også åben for tekniske indgreb.

Historisk set var fremkomsten af den kliniske lægevidenskab parallel med fødslen af den moderne psykiatri, og man adopterede da også hurtigt den kliniske rationalitet i psykiatrien. Eftersom den kliniske medicin havde påvist, at feber og lignende var sygdomssymptomer på forstyrrelser af de normale livsfunktioner inde $\mathrm{i}$ kroppens væv og organer, fik en del af det 19. århundredes psykiatri, med Franz Joseph Gall i spidsen, smart nok også den idé, at de sindssyges vanvittige tanker og adfærd tilsvarende måtte være symptomer på forstyrrelser af hjernens normale funktioner. Det førte til neuropsykiatrien, der netop blev født med tilsagnet om at kunne påvise en kobling mellem psykopatologiske symptomer og neurologiske dysfunktioner. Og dermed levere et stringent naturvidenskabeligt grundlag for psykiatrien og således løfte den ind i det gode videnskabelige selskab. Neuropsykiatriens bestræbelse lykkedes imidlertid ikke i første omgang, og oven i købet fik foretagendet plettet sit rygte ved at placere sig på den forkerte side af skranken i det tredje riges eutanasiprogrammer. Når det skal nævnes, er det netop fordi Rose og Abi-Rached i realiteten bruger en del af pladsen i Neuro på at ajourføre os på de nyeste aspekter af den fortælling. Aspekter, som da også har tiltagende relevans i vores nære samtid, hvor forekomsten af psykiske sygdomme nærmest synes at eksplodere. Men i den forbindelse gør Rose og Abi-Rached faktisk et nummer ud af at fortælle, at selv om neuropsykiatrien har fået en renæssance i de seneste årtier, så er det heller ikke i det 21. århundrede lykkedes at påvise nogen entydig kobling mellem psykopatologiske symptomer og neurologiske dysfunktioner.

For at betrygge kritikere og skeptikere endnu mere, forsikrer Rose og Abi-Rached os om, at neurovidenskaberne heller ikke har medført en neuroreduktionisme, idet de ikke identificerer mennesket med dets hjerne eller forklarer os som styret af hjernen. Forbindelsen mellem neurovidenskaberne og den moderne kriminalitetskontrol har heller ikke ført til, at man har suspenderet idéen om det autonome retssubjekt med en fri vilje, selv om vi til gengæld kan forudse bestræbelser på at styre antisociale borgere ved at intervenere i udviklingen af deres hjerne. Endelig rummer neurovi- 
denskaberne heller ikke en forfladigelse af selvet, men involverer en videreføring af de seneste årtiers opfattelse af selvet som bundet af en forpligtelse på autonomi og selvopfyldelse samt et ansvar at forbedre sig selv gennem hele livet - som den tyske filosof Peter Sloterdijk påpegede i værket Du mußt dein Leben ändern fra 2009.

Rose og Abi-Rached har på sin vis bedrevet et aldeles glimrende værk, der giver en god indsigt i de nye neurovidenskaber og deres indflydelse på vores selvforståelse og -forvaltning i begyndelsen af det 21. århundrede. Værket formår også at opretholde sin sikkerhedsorienterede ambition fra begyndelse til ende, og det er meget svært at få kaffen galt i halsen over Neuro. Men skal vi skvulpe lidt i koppen, er værket også symptom på en meget konsensussøgende og endimensionel samtid, hvor mennesket bliver stadig mere viklet ind i og forblændet af sig selv. Her i 200-året for Søren Kierkegaards fødsel, kan vi derfor passende gentage hans elev Martin Heideggers udsagn fra 1976 om, at "Nur noch ein Gott kann uns retten".

Anders Draby Sorensen 